Theatre Research in Canada

Recherches théâtrales au Canada

\title{
Review of revues
}

\section{Louise Forsyth}

Volume 39, Number 2, 2018

URI: https://id.erudit.org/iderudit/1058050ar

DOI: https://doi.org/10.7202/1058050ar

See table of contents

Publisher(s)

Graduate Centre for the Study of Drama, University of Toronto

ISSN

1196-1198 (print)

1913-9101 (digital)

Explore this journal

Cite this document

Forsyth, L. (2018). Review of revues. Theatre Research in Canada / Recherches théâtrales au Canada, 39(2). https://doi.org/10.7202/1058050ar

All Rights Reserved (c) Theatre Research in Canada / Recherches théâtrales au Canada, 2019
This document is protected by copyright law. Use of the services of Érudit (including reproduction) is subject to its terms and conditions, which can be viewed online.

https://apropos.erudit.org/en/users/policy-on-use/
This article is disseminated and preserved by Érudit.

Érudit is a non-profit inter-university consortium of the Université de Montréal, Université Laval, and the Université du Québec à Montréal. Its mission is to promote and disseminate research.

https://www.erudit.org/en/ 


\section{Review of revues}

LOUISE FORSYTH

This review deals with the four journals having a focus only on theatre and the performing arts in Québec: Feu. Revue de théâtre, Annuaire théâtral. Revue québécoise d'études théâtrales, Alt. theatre. Cultural Diversity and the Stage, Aparté. Arts vivants-recherche et création. ${ }^{\mathrm{I}}$ Each of the journals has its range of critical approaches, practical and theoretical interests, unique readership. Together they provide specific information, as well as an overview, on what has been going on recently in theatre, performance, and the many other living arts in Quebec. I am hoping that this review will be an instrument for listening to probing critical perspectives, dynamic creative initiatives, commentaries, and critiques on the challenges faced by theatre in contemporary society. I offer an idea of some of the exciting new theatrical work in Quebec, innovative theoretical approaches, and the most urgent current issues, spilling vigorously onto public spaces, that are currently preoccupying members of performing arts communities and their critics.

Quite fierce initiatives to tear down the walls that protect and preserve the canon, autonomous, institutionalized artistic disciplines, and the media that preserve their centrality in public spaces are in the air on the Québec theatre scene. In this climate, interdisciplinarity is facilitating unconstrained creativity, co-creation, indiscipline, dialogue, improvisation, play, collaborative experimentation, disruption of established conventions, codes, and traditions. Spectators are interpellated to be active participants in innovative adventures. Such interdisciplinarity and artistic recontextualization are serving to crack open established bases of theatre practice, examine theatricality in perspectives not previously studied analytically or in practice, and throw into question lingering practices and values that lend themselves to arbitrary closure in languages and forms and that continue to privilege inequitable traditions. Wide-ranging interdisciplinarity may include collaboration among any number of existing or newly invented arts, such as theatre, dance, music, visual art, poetry, circus, puppetry, performance art, cinema, and animation.

However, despite this openness, Quebec's theatre journals show that all is not sweetness and light on the theatre and performing arts scene in the province. In addition to shifting public support and conflicting tastes regarding what theatre should be about in an era when social media have radically transformed conversations, tastes, and activities on the cultural commons, voices are urgently making themselves heard calling for action toward achieving equity and diversity. There are many whose stories and experiences have never been appropriately represented in the theatres and performance spaces of Quebec. Where do theatre and the performing arts fit in twenty-first century Quebec society, with its mosaic of cultures and new technologies? Who has the legitimacy to be heard in public, to perform on today's stages? To tell whose stories? To represent whose history, experiences, and aspirations? In whose words? In the name of what communities? What is the impact of enhanced spectators' agency? What is pedagogically appropriate for today's theatre students? What is the 
nature of their agency? In what spaces? What can collective creation do in today's world? Can theatre and the performing arts done differently produce new forms of knowledge and so lead to social change?

Above all, and underlying all movements for change on the Quebec scene, particularly those of young and impatient generations, are insistent demands for greater diversity than has ever characterized practices, languages, values, stories, spaces, codes, and conventions in theatre and the performing arts. Opinions that refuse to be denied stress consistently in theatre journals that the performing arts are living arts that must regain and reclaim their touch with the heartbeats of all humanity.

\section{Jeu. Revue de théâtre (founded 1976)}

feu publishes four issues annually. It covers a broad range of the performing arts, keeping an ongoing and invaluable historical record of their happenings, addressing practical concerns, and encouraging multi-directional and critical dialogue, raising theoretical questions regarding theatrical practice, criticism, education, and relevance. Like all the journals I discuss here, every issue of $\mathcal{f e u}$ is rich with photos and eloquent art work. feu reports on theatre events and publishes opinion pieces, news items, interviews, and articles by theatre artists, directors, designers, choreographers, critics, scholars, educators, theatregoers, and students.

feu put a new format in place in 20I4. Readers can now count on reaching the end of each issue on page 96 and on finding consistently an editorial page, two short columns, a one-page Coup de gueule, ${ }^{2}$ a thematic dossier containing nine articles, articles on other topics (usually eleven), and a final piece dedicated to a pioneer or some historical matter.

\section{Jeu. Revue de théâtre, 164 (2017.3)}

The thematic dossier of this issue, "Publics," is centred on reception and spectatorship. Articles here reflect concern about the composition of theatre audiences and those who might potentially become audience members. In highlighting the important place of publics in the very survival of theatre and live performance, there is acknowledgement that encounters and exchanges between stage and house, and experimentation with the fourth wall, have been transformed in new, creative ways, and that notions about who attends and appreciates live theatre, what competence and interests they bring, and why they decide to come are no longer the same as they once were.

Raymond Bertin launches the issue by affirming the need to attract new audiences: "Ce dossier souligne l'importance pour l'écologie de la création théâtrale de conquérir de nouveaux publics, de convaincre, de séduire, de fidéliser des adeptes plus nombreux des arts du spectacle vivant" ( $\mathrm{I} 3$ ). He is concerned about perceived elitism in the theatre sector. Neither theatre practitioners nor their publics reflect the full diversity of society, where segments are excluded by reasons of class, ethnicity, and gender. Articles highlight the role of educators in producing competent and loyal theatregoers. In particular, the dossier shows that the traditional one-size-fits-all assumption regarding spectators' silent and passive appreciation and understanding of any particular show has now been replaced by a respect for spectators as active creators playing essential roles as interpreters of incessantly mobile scenes. 
The Coup de gueule in this issue, "Apprendre à compter," is a protest against the longstanding and ongoing marginalization of female playwrights and directors. It is written by spokeswomen of the collective Femmes pour l'Équité en théâtre (FET), Marie-Ėve Milot and Marie-Claude St-Laurent, ${ }^{3}$ who gathered shocking statistics on programming over the five previous years at all major theatres in Montreal and Quebec. Pieces by women continue to occupy between 20 and 30 percent of programmes, despite women being the majority in schools and audiences. The authors stress that the picture of the inequitable representation of women playwrights and directors in the performing arts would be that much more disheartening if the methodology had involved an intersectional approach.

This report was far from the first study of systemic inequity in Quebec theatre. It is, rather, a continuation and expansion of protests and demands for change which began several years earlier, including angry plays, ${ }^{4}$ reports, and special theme issues in $\mathrm{feu}$. There was Marie-Ève Gagnon's study Le Rideau de verre. Auteures et scènes québécoises (2009), created for l'Association québécoise des auteurs dramatiques. There was also Annick Lefebvre's Coup de gueule, "GO à quoi?", which appeared in dossier 156 of $\mathcal{F e u}$ on "Nouveaux territoires féministes" in 2015 (3). In this piece, Lefebvre hurls powerfully aggressive allegations at Ginette Noiseux, artistic and administrative director of Espace GO, accusing her of being untrue to the feminist mission of the company as heir to the Théâtre Expérimental des Femmes (founded in 1979) in failing to produce recent new works by emerging female playwrights.

\section{Jeu. Revue de théâtre, 165 (2017.4)}

The theme of the nine articles that make up the dossier of this issue is "Liberté d'expression." As current events surrounding the cancellation of Robert Lepage's most recent creations have shown, "freedom of expression" can be a dicey matter, particularly when it raises issues of cultural appropriation.

The opening article in this dossier provides an historical overview of censorship imposed for centuries on the theatre in Quebec by religious and political forces who never relented in their efforts to maintain the absolute control and power enjoyed by the ideological positions at the centre of their authoritarian institutions. Its articles show that while the power of institutionalized censorship no longer enjoys absolute control in society's affairs, at least in the Western world, there are still forces exercising effective power to deny freedom of expression, silence voices, stifle or distort stories, and produce invisibility for many who are seen to belong to inferior or dangerous groups. Censorship does not express itself here in similar ways through official declarations, but rather through taboos, stereotypes, and unspoken bias, playing on people's fears and prejudices which may manifest themselves in covert, unjust, or violent actions and in the kind of learned discretion that produces self-censorship. Social norms that deny the legitimacy of freedom of expression for members of disadvantaged or oppressed groups (along with access to the means to exercise such freedom) serve to perpetuate oppression, often in violent ways.

Articles in the dossier reflect research done in many areas, for example on limitations imposed on educators intending to address such thorny questions as terrorist recruitment, criminality, sexuality, cultural appropriation, or class-based injustices. The dossier contains interviews with four extraordinarily gifted female playwrights who have had to deal 
with arbitrary walls limiting their freedom of expression, silencing their words, and erasing their creative works: Brigitte Haentjens, Annick Lefebvre, Catherine Léger, and Dominick Parenteau-Lebeuf.

The Coup de gueule in this issue, "L'art n'est pas un outil," is a protest against the influence of neoliberal values on decisions of public financial support for theatre artists and companies.

\section{Jeu. Revue de théâtre, 166 (2018.1)}

The theme of this issue, "Littérature et scènes," provides insight into a range of instances of interplay and exchange between literature and the performing arts. The dossier is a rich overview of spectacles drawing their energy through interdisciplinarity when the theatricality of literature (all genres, including non-fiction) and the multiplicity of media of theatre and performance (text and stage) are explored by visionary and daring artists. The dossier begins with an exchange of letters between playwrights and novelists Fanny Britt and JeanPhilippe Baril Guérard, in which they explore the creative possibilities of conjoining more than one genre.

James Oscar's Coup de gueule, "Bilan critique 2017: le FTA reflète-t-il vraiment «les Amériques »?", challenges the overwhelming whiteness of artists and critics of the 2017 Festival TransAmériques. Oscar's ironic address to decision makers bears on "la myopie grotesque dans laquelle vous vous noyez, dans laquelle vous vivez, de laquelle vous profitez" (II).

"L'arsenal redoutable des jeunes romancières" is a comparative study of several innovative first novels by young female writers adapted recently for the stage. The pieces cause personal voices to be heard in their frequently autobiographical explorations of self-identity, love, sexuality, death, and social reality. "Du livre à la scène" (26-30) reflects in considerable detail on the process involved in bringing a work of fiction to the stage. "Quand l'auteur se fait personnage" $(3 \mathrm{I}-35)$ studies and compares the many contemporary plays in which the main character is an author. "Le théâtre en livres, pour quoi faire?" (36-40) poses the eternal question of the meaning and practical purpose of dramatic texts. "Pour une nouvelle poétique de la scène" (4I-44), a conversation among three theatre artists, is a compelling reflection on the added dimension poetry brings to theatre through the voices and bodies of the actors. "La grande bibliothèque de Loup bleu" (46-49) reminds us of the remarkable work of the Théâtre du Sous-marin jaune, directed by the puppet Loup bleu, specializing in stage adaptations of the world's classics for general and young audiences. "Danser les mots" (50-53) speaks of contemporary choreographers who step away in interdisciplinary and intercultural ways from the conventional narrative forms of classical ballet in order to allow dansers' bodies to tell the stories and capture emotions.

\section{Jeu. Revue de théâtre, 167 (2018.2)}

Pursuing feu's sustained support for real change in theatre with the combined objectives of equity and diversity, the editorial page, "Vent de changement," launches this issue with these words at the centre and in red: "Feu se fait à nouveau l'écho d'un mouvement de prise de parole par les femmes artistes, une irréversible (r)évolution en marche dans notre monde culturel" (I). 
The thematic dossier of this issue is devoted to actor, director, theorist, writer, teacher, and company founder Christian Lapointe, a theatre phenomenon who has stirred extreme admiration in Quebec and beyond for his powerful originality, the mysterious and magical qualities of his creations, his bold departures, and his innovative practices with audiences. The articles that make up the dossier offer first-hand accounts by artists who have co-created with Lapointe (actors, writers, directors, designers, and teachers). They provide testimony to Lapointe's use of theory in intensely energized poetic and corporeal practice. The final text is an interview with Brigitte Haentjens, who directed Lapointe in $201 \mathrm{I}$ in Swedish playwright Lars Norén's The 2oth of November. Haentjens sponsored Lapointe in 2007 when she was awarded the Siminovitch prize for her own outstanding work in theatre.

The Coup de gueule of this issue is signed by a collective of Montreal choreographers opposed to the creation of the Prix de la danse de Montréal because they connote elitism and social hierarchy. For these artists, the ongoing functioning of these prizes reflects neoliberal values detracting from the encouragement of real artistic achievement.

Other issues in dance return in later articles as the subject of Guylaine Massoutre's "Danse Danse: diffuser la création en répondant aux attentes du public" (88-89) and Mélanie Carpentier's "Sexisme en danse: le mur du silence s'effrite au Québec" (68-7I).

The final section of this issue, "Mémoire," departs from the normal practice, whereby homage is paid to a single theatre artist. This article, "Écrire, disent-elles," features the research of Lucie Robert on generations of women playwrights who wrote for theatre between the final years of the nineteenth century and the r970s. Robert's research effectively puts to rest the notion that there were no women writing for theatre before recent decades.

\section{L'Annuaire théâtral. Revue québécoise d'études théâtrales (founded 1985)}

L'Annuaire théâtral, a peer-reviewed scholarly journal, had an interruption in the rhythm of its publication over the last year. After issue 59 (2016), no issues appeared before issues 60 and $6 \mathrm{I}$ in June 20I8. The journal's established calendar of two issues per year is now almost back on track.

\section{L'Annuaire théâtral. Revue québécoise d'études théâtrales, 60 (automne 2016)}

The theme of this issue, "Pratiques interdisciplinaires. Processus de création en arts vivants," depicts a radical perspective on interdisciplinarity in all articles which reflects the generalized dissatisfaction with the traditional boundaries of fixed, institutionalized artistic disciplines. This bold approach to the meaning and practice of interdisciplinarity is associated throughout this dossier with the conjoined field of "recherche-création" (practice-based research/ artistic research), bringing together in intimately associated creative practice movement and thought, body and mind, materiality and imagination. Research and creation working together has striking impacts on the representation of space (hybrid, impermanent, mobile) where unexpected encounters, deterritorialization, and transgression prove most fruitful. Reality and fiction co-exist and interact in the fluid and open contexts of interdisciplinarity, 
intermediality, and a limitless range of interartistic practices. Articles in this dossier study and analyze instances of interdisciplinarity in dance, theatre, music, visual arts, and other performance arts.

In "Arts vivants et interdisciplinarité: l'interartistique en jeu” (13-25) Marie-Christine Lesage provides a thoughtful and well-researched overview of disciplinarity and interdisciplinarity, as they have been and as they are evolving. Initiatives in interdisciplinary practice inevitably produce questions regarding disciplinary norms, including theatrical norms.

In "Multi-modalité et hybridité de la diffusion de la recherche-création: le point de vue des chercheurs-créateurs" (27-47), Chantal Provost examines problems for publication of academic research deriving from theatrical practice. The conventions surrounding academic research, based entirely on discursive paths, impose limits that prevent the many non-verbal languages of performance from being appropriately appreciated. In "Quand la mobilité répond à l'ouverture multimodale d'une recherche-création en théâtre" (49-74), Jean-Paul Quéinnec reports on his work with a group moving outside symbolic and material walls, doing research on sound (acoustic, electronic, environmental), on performativity, and on different and incessant manifestations of instability and mobility. Its members created a marginally theatrical show in different places using a range of transmedial forms beyond the confines of established methodologies. Marie Mougeolle's "Le collectif comme mode d'intervention: Perturbations de La 2e Porte à Gauche" (75-89) takes the reader into a dance workshop during which participants explored their personal and collective responses to the question "Qu'est-ce que la danse peut produire (d'autre)?" The objective of the workshop was to perturb and displace, to use the capabilities of art to infiltrate reality and its structures (artistic, disciplinary, or institutional) so as to reflect and inflect the norms that "go without saying" in the discipline of dance. Johanna Bienaise describes a different kind of interdisciplinary initiative in "D'une interdisciplinarité-processus à une interdisciplinarité-œuvre: La très excellente et lamentable tragédie de Roméo et fuliette de Catherine Gaudet et Jérémie Niel" (9I-IO3). This article explores the process of finding a basis for dialogue and dramaturgical collaboration across, through, and despite the disciplinary boundaries, conventions, and norms of dance and theatre. This led to the creation of a new kind of art, an unstable, impermanent hybrid art, bringing to light different ways of participating in the creative experience, of being otherwise in space, of freeing oneself from the constraints involved in doing disciplinary work. In "Les résonances de l'intime par la rencontre corpsvoix-texte chez l'interprète en danse” (I05-I6), Manon Levac recounts her experience as a dancer in the creation of two dance productions choreographed by Jean-Pierre Mondor and Sarah Chase using the unusual creative process of performances involving dance, writing, and speaking text. Interdisciplinary dance artist Angélique Wilkie reflects, in "Création interdisciplinaire et indiscipline de l'interprète-créateur" (II7-3O), on her work as an artist/ performer nourished by an interdisciplinary mode. The relation with her primary discipline transforms as she explores tensions in the spaces between them, spaces of creation and discovery where she finds a new sense of identity and personal autonomy.

This dossier on "Processus de création en arts vivants" is followed by three "Documents" that serve as illustrations of other actual "Pratiques interdisciplinaires" and reveal strategies, in one case a sort of comic strip, that emerged to make the collaborations work aesthetically and, sometimes, politically. 
The two independent articles in this issue of L'Annuaire théatral are excellent studies of the tragic in Wajdi Mouawad's tetralogy Le sang des promesses (Littoral, Incendies, Forêts, Ciels) and of the life and art of eighteenth century French actress, Mademoiselle Clairon.

\section{L’Annuaire théâtral. Revue québécoise d'études théâtrales, 61 (printemps 2017)}

The theme of this issue is the brilliant and extraordinary career in theatre of author and director Brigitte Haentjens: "Brigitte Haentjens. Mouvances du texte et imaginaires du féminin." Haentjens received the Siminovitch and Gascon-Thomas prizes in 2007 and the Prix du Gouverneur général pour les arts du spectacle in 2017. She has been artistic director of the French Theatre of the National Arts Centre in Ottawa since 20I2. Like the previous issue of L'Annuaire thêatral, this one begins with a "Mot des Directrices," followed by the dossier of scholarly articles and then "Documents" providing three artists' feedback on Haentjens' 2016 theatrical adaptation/re-creation of Marta Hillers' journal Une Femme à Berlin. This section closes with an interview with Haentjens on the subject of critical reception of her work, "Aimer, sans complaisance ni indulgence: discussion sur la critique avec Brigitte Haentjens" (I65-75).

The issue also contains a section devoted to "Recherche-création," recounting experiences of shows created with and by people who have no theatre or dance experience or training - "présence scénique brute" (unprocessed stage presence, 179)-and who are likely to be seen as members of social groups whose stories are rarely represented on stage.

Jeanne Bovet begins her introductory piece, "L'œuvre au corps," by stating that both Haentjens and her work are "exigeante, rigoureuse, passionnée, inquiète, ouverte, généreuse" (5). This work is characterized by a central preoccupation with the performativity and creativity of bodies, as well as the violence done to them, as they are fantasized and represented in texts and women's experience. Bovet remarks that despite the extraordinary quality of Haentjens' work over several decades, she has received relatively little scholarly study or analysis.

The historical piece "Brigitte avant Haentjens: un engagement artistique en Ontario français" (I5-4I) by Louis Patrick Leroux follows the young "Brigitte" Haentjens as she became an intensely committed theatre artist. Alexandre Cadieux's "L'émergence de Sibyllines: une construction collective" (43-66) shows Haentjens positioning herself in Montreal as a bold and highly original theatre artist. "La performativité du corps féminin dans le théâtre de Haentjens: quatre illustrations" (67-92) by Gabrielle Lalonde explores Haentjens' directorial deconstruction of gender norms through invention of innovative performance strategies. Esther Laforce analyzes Haentjens' adaptation of Ingeborg Bachmann's novel Malina in "Les chambres fermées dans Malina" (93-115) while showing the stifling impact of ideologically determined static space on the female character. Mélanie Dumont provides, in "Accompagner Brigitte Haentjens, mouvements d'une dramaturge" (II7-29) an account of her personal experience as dramaturg collaborating occasionally for ten years with Haentjens and thereby participating profoundly in the movements of her richly creative mind. Sara Thibault and Hervé Guay study eight plays produced over almost twenty years by Haentjens in "Sorties du théâtre: pratiques de l'interartistique chez Brigitte Haentjens" (I3I-48). They consider 
her breaking out of conventional spaces and implicit understandings between actors and spectators through the integration of languages and practices drawn from, for example, performance arts, dance, choruses, and environmental theatre.

\section{Alt.theatre. Cultural Diversity and the Stage (founded 1998)}

Alt.theatre, an anglophone journal published three times per year by Montreal's plurilingual Teesri Duniya Theatre, presents itself as "Canada's only professional journal examining intersections between politics, cultural plurality, social activism and the stage” (https:alttheatre. ca/about/, consulted 3 October 20I8). The website of Teesri Duniya Theatre affirms that it is "dedicated to producing, developing and presenting socially and politically relevant theatre, based on the cultural experiences of diverse communities. Multicultural diversity, intercultural relations, relevance and compelling stories are defining features of our work. We are committed to multiethnic (as opposed to color-blind) casting" (www.teesriduniyatheatre. com/fr/accueil, consulted 3 October 20I8).

\section{Alt.theatre. Cultural Diversity and the Stage, 13.3 (2017)}

Editor in chief Michelle MacArthur addresses stubbornly enduring stereotypes and established discriminatory practices disadvantaging women in "The Feminist Killjoy Goes to the Theatre" (8-II). The editorial speaks powerfully in favour of frank protest and shared compassion among the oppressed, as opposed to social pressures that encourage silence or "sucking it up." MacArthur celebrates the potential of theatre and the performing arts to support such protest.

Aaron Franks explores, in “O K'inādās-Where Ayumi Goto and Peter Morin Do Not Talk about Reconciliation" (I2-I9), the need to go boldly beyond mere reconciliation in performance languages and practices. The script of Sarah Waisvisz's disturbing one-woman play Monstrous, on mixed-race identity and which had just premiered in Ottawa, is published in its entirety. This issue also offers the fifth and final piece, "Being the Fifth Bear" (3I-35), of a series curated by artist Donna-Michelle St. Bernard. "The Principles Office" (PrOf) that ran through volume $\mathrm{I} 3$ of $A l t$, and is dedicated to the production of ethno-cultural, holistic change in the performance community. Kingston festival performers Rebecca Benson and Tracey Guptill are interviewed by the fictional characters they played in "Anybody Can Be Pussy Riot" (36-38). Reviews include discussions of the production Bittergirl-The Musical on Citadel Theatre's Club Stage in Edmonton, and of the edited volume Staging Intercultural Ireland: New Plays and Practitioner Perspectives.

\section{Alt.theatre. Cultural Diversity and the Stage, 14.1 (2017)}

MacArthur's editorial for this issue, "Protest and Performance," provides insight into performative acts offering spaces of resistance and nurturing gestures of protest as forms of art that succeed in making people imagine something that is not there.

Lina de Guevara describes, in "Where Police and Community Meet" (IO-I6), two community-arts projects in Victoria, BC that workshop material with police officers and 
immigrant refugee communities, adapting techniques from Augusto Boal's Theatre of the Oppressed to develop dramatic scenes subsequently presented to both groups to look at critical issues that affect their relationships. Preeti Chaliwal uses theatre, poetry, and performativity in interdisciplinary ways in "Re-embodying Jurisprudence" (I7-25) to explore and make the reader feel how law lives in the body, how we embody law, how theatre has the potential to show law to be creative and accessible, and how performance can become a way for people to rehearse for social change. "A Return to Place" and "Peter Morin: Expert Time-Travel Conductor" (26-32) are personal accounts of the encounter, involving embodied research, by Mariel Belanger, Syilx artist, performer, scholar and student, over several years with the University of British Columbia-Okanagan Summer Indigenous Art Intensive. Priya Nair reflects on bridging cultural and linguistic divides (Syrian, Chilean, anglophone) through theatre in Montreal in "Checking into The Refugee Hotel in Montreal" (33-34). Reviews of Louis Patrick Leroux's Hamlet on the Wire/Hamlet sur le fil (during which Hamlet actually walks on a tightrope) and of Rustom Bharucha's Terror and Performance (35-39), in which he develops his distrust of violence when it is seen as theatre, are both probing descriptions and analyses.

\section{Alt.theatre. Cultural Diversity and the Stage, 14.2 (2018)}

The editorial in this issue, "Systemic Discrimination Creates Cultural Hegemony in the Arts” (8-9) written by Rahul Varma, author, founder , and artistic director of Teesri Duniya Theatre, and co-founder of Alt.theatre, offers a convincingly formulated allegation that the Conseil des Arts et des Lettres du Québec (CALQ) discriminates against indigenous and racialized persons as well as against English-speaking minorities and, at the same time, normalizes the cultural order of white francophones. The editorial provides specific details and shows that statistics are manipulated by the CALQ through its failure to implement intersectional methodology.

Kate Krug and Sheila Christie discuss their use of performance in the 2015 Cape Breton Lumière Festival to bring about social change in "Community Trans/formation: Performing Transgender Children's Narratives in Gendered and Nongendered Spaces” (IO-15). Sarah Robbins presents the fruits of her in-depth conversation with Hope McIntyre, founder and artistic director of Winnipeg's Sarasvàti Productions: “FemFest 2017: Coming of Age'Filling the Gaps and Adapting to Change" (I6-2I). McIntyre's emphasis on gender equity and socio-ethnic diversity in theatre leads her to associate the fifteen-year-old FemFest festival with today's \#MeToo and \#TimesUp movements, and also highlights connections with reports on the inequitable status of women in theatre done over the past several decades by Rina Fraticelli (1982), Rebecca Burton (2006), Marie-Ève Gagnon (2009), Michelle MacArthur (2015), and Femmes pour l'Équité en théâtre (2017). McIntyre reflects on what needs to happen in order to produce real change on the theatre scene.

In a return to the 2018 series launched in the Alt.theatre I4.I issue, the theme "A Return to Place-Embodied Story Practice" (22-28) is explored in the next five articles from a range of perspectives and with interdisciplinary references to the specific instance of the transformative construction led by Mariel Belanger of a tule mat lodge on the UBC Okanagan campus: "Ancestral Village Practices Performed on Campus," "Reflections on the 'tukwtnitxw-Tule 
Mat House': Indigenizing the Built Environment," "Reflections on Constructing the Tule Lodge," "Under Construction," and "Nde' Poetics: A Daughter of Rivered Remembering inside the Tule Mat Lodge." This building project shed light on the connections among indigenous architecture, frameworks for governance, and women's place in village social life, and provided a new, emerging space for inner journeys and indigenous being, knowing, doing, and repairing-beyond borders, walls, myths, and war.

Kristjanna Grimmelt writes, in "Juggling in El Salvador" (29-30), about the creative partnership between El Salvador's Primer Acto and Canada's Stratford Festival. The review of Tarragon Theatre's 2017 production of d'bi.young anitafrika's dub opera Lukimi is an experiment in offering opinions of cast members of a production in place of the voice of a single external critic. Yeliz Biber Vangölü's review of Bim Mason's Provocation in Popular Culture, which studies relations among provocative acts of risk-taking, power, popularity, and playfulness, discusses its interesting qualities, while drawing attention to the book's theoretical weaknesses, particularly in the analysis of the effectiveness of provocative women artists in popular culture.

\section{Aparté. Arts vivants-recherche et création (founded 2011)}

Aparté is a scholarly journal founded by graduate students in theatre at l'Université du Québec à Montréal. The journal's full title highlights the liminal position its founders are assuming and proclaims the consequently transgressive views for which it intends to be a vehicle. Its focus is on works in which mind and body are simultaneously engaged from the start, hybrid creations where research is materially and explicitly woven into creative practice. The journal claims identity as an aside, not participating in centre-stage dialogue, stressing its commitment to that which is dynamic, moving, and living in the arts. The themes of the four issues of Aparté that have appeared to date highlight the objective of producing change by exploring poetically, imaginatively, corporeally, and experimentally that which has been lying in the cracks and fissures of dominant discursive practices and thought, all the while nurturing the disruptive epistemological and political ramifications produced as a result of the journal's chosen position.

Articles in the first issue of Aparté, "Débordements: pratiques en périphérie de la scène," stress liminal practices moving into fields of indeterminacy and indiscipline, while highlighting the anticipated process of flowing over and beyond established boundaries.

The general frustration demonstrated here by the young who perceived a lack of support for the arts and education in a society they saw as stagnating was already apparent in the early years of the twenty-first century. This ferment received an invigorating injection in 2012 when the massive student demonstrations and strikes of Le Printemps érable brought thousands to the streets. Apartê's second issue, "Actes sexués: postures subversives du genre" (2013), explicitly associated itself with the Maple Spring, underlining the central importance of the body's expressivity in theatrical creativity. As Véronique Hudon states in her editorial, "Pour une histoire des femmes: performativité de la résistance," "les revendications s'expriment par la chair" (3). Contributors to the third issue of Aparté, "Doute et inventivité: récits de recherche-création pour une scène indéterminée" (20I4), reflect on the combined perspectives of research and material practice, whereby scholars and theoreticians emerge 
from their ivory towers and move to share research questions, as well as physical and conceptual space, with practitioners.

The theme of the latest issue of Aparté, "Les temps collectifs" (4.2017), is an exploration of ways for theatre ensembles to work in the twenty-first century. The subtitle of the issue's anonymous editorial, "Dérives et dérivations du collectif. Comment penser les pratiques actuelles" (2-7), acknowledges the challenge of making collaboration work in the absence of a clearly defined and lasting common sociocultural purpose.

\section{Notes}

I Lucie Robert's regular column, Dramaturgies, in Voix et images is particularly important.

2 The one page Coup de gueule is made available every month to those who are strongly indignant about some controversial aspect of theatre and the performing arts and wish to make their view loudly and widely known, without having to worry too much about whether what they are saying and how they are saying it is likely to be considered "nice."

3 Milot and St-Laurent co-founded the Théâtre de l'Affamée in 2009. It is a company that has boldly and aggressively affirmed the legitimacy of feminist theatre.

4 For example, Annick Lefebvre's F'accuse. Montréal: Dramaturges Éditeurs, 2015, created at the Théâtre d'Aujourd'hui in April 2015. 